\title{
WPLYW KONWENCJI MIĘDZYNARODOWEJ ORGANIZACJI PRACY NA LEGALIZACJĘ WOLNOŚCI ZRZESZANIA SIĘ W ZWIĄZKI ZAWODOWE W POLSCE DWUDZIESTOLECIA MIĘDZYWOJENNEGO
}

\author{
IMPACT OF THE INTERNATIONAL LABOR ORGANIZATION CONVENTION \\ ON LEGALIZATION OF THE FREEDOM TO FORM TRADE UNIONS \\ IN POLAND IN THE INTERWAR PERIOD
}

The very nature of all the acts adopted by the International Labor Organization was that in their preparation there were directly involved, on equal terms, representatives of governments, trade unions and employers' organizations. The basic documents adopted within the framework of the ILO since the very beginning of its functioning had been conventions. Poland was one of the founders of the International Labor Organization and has often undertaken activities aimed at fully realizing its aims and enriching its normative output. The standards established by the ILO have also influenced the Polish law on trade union freedom. This was due to the obligations resulting from the ratification of the Convention and the creation of informal pressures to bring the content of domestic law into line with international standards. Equally important was the mode of setting standards within the ILO. It expressed a particular mechanism of functioning of this international organization, without precedent in other organizations.

Słowa kluczowe: zrzeszanie, wolność, związki zawodowe, Międzynarodowa Organizacja Pracy, Polska

Key words: associating, freedom, trade unions, International Labor Organization, Poland

* Dr Marcin Kazimierczuk, Uniwersytet Warmińsko-Mazurski w Olsztynie, Wydział Prawa i Administracji; marcin.kazimierczuk@uwm.edu.pl

\section{WPROWADZENIE}

$\mathrm{P}$ opieranie rozwoju wolności zrzeszania się w związki zawodowe i innych wolności związkowych należało do głównych kierunków działania Międzynarodowej Organizacji Pracy [dalej: MOP] ${ }^{1}$. Ta jedna z najstarszych organizacji międzynarodowych, działająca nieprzerwanie od 1919 r., pierwotnie była częścią Ligi Narodów ${ }^{2}$. Polska była jednym z państw założycieli MOP i niejednokrotnie podejmowała działalność zmierzającą do pełnej realizacji jej założeń oraz wzbogacenia dorobku normatywnego. Historycznie MOP była wytworem dziewiętnastowiecznej myśli społecznej. Ekonomiści i socjologowie stwierdzili, że sytuacja robotników w czasie rewolucji przemysłowej jest niewłaściwa. Społeczni reformatorzy, począwszy od Roberta Owena, wierzyli, że każdy kraj usiłujący poprawić warunki pracy zwiększy koszty produkcji, stawiając się w niekorzystnej ekonomicznie sytuacji w porównaniu do

1 Vide L. Florek, M. Seweryński, Międzynarodowe prawo pracy, Warszawa 1988, s. 110 i n.

${ }^{2} \mathrm{Na}$ temat historii MOP m.in. napisali: J. Follows, Antecedents of the International Labour Organization, Oxford 1951; L. Betten, International Labour Law. Selected Issues, Deventer-Boston 1993. 
innych krajów. Dlatego starali się oni przekonać możnych Europy, aby lepsze warunki pracy, krótsze godziny pracy oraz wolności związkowe stały się przedmiotem międzynarodowych porozumień.

Wpływ norm stanowionych przez MOP na prawo krajowe rzuca pewne światło na proporcje, w jakich pozostają względem siebie wewnętrzne i zewnętrzne przyczyny rozwoju ustawodawstwa związkowego. Jednak ranga tego problemu wynika stąd, że zakres i skuteczność oddziaływania międzynarodowego prawa pracy na krajowe systemy prawa stanowi podstawową przesłankę oceny samej organizacji, czyli jej zdolności realizowania przyjętych założeń oraz roli odgrywanej w kształtowaniu stosunków międzynarodowych.

\section{GENEZA MIĘDZYNARODOWEJ ORGANIZACJI PRACY}

Po zakończeniu I wojny światowej, na konferencji pokojowej w Paryżu, na wniosek związków zawodowych z kilku krajów powołano 25 stycznia 1919 r. Komisję Pracy do opracowania zadań i struktury organizacyjnej stałej organizacji międzynarodowej, która miała między innymi czuwać nad respektowaniem „zasady wolności związków"3. Wśród jej 15 członków byli związkowi przywódcy tacy jak Amerykanin Samuel Gompers, który został przewodniczacym oraz Leon Jouhaux z Francji, późniejszy laureat Pokojowej Nagrody Nobla. W Komisji byli również liderzy Międzynarodowego Stowarzyszenia Ustawodawstwa Pracy: Arthur Fontaine z Francji (pierwszy przewodniczący Rady Administracyjnej MOP), Ernest Mahaim z Belgii (następca Fontaine'a), przywódca socjalistyczny Emile Vandervelde z Belgii i Harold Butler z Wielkiej Brytanii, późniejszy dyrektor generalny MOP. Po 10 tygodniach pracy Komisja Pracy przyjęła dokument, opracowany na podstawie brytyjskiego projektu, który 11 kwietnia 1919 r. został włączony do traktatu wersalskiego jako jego XIII rozdział ${ }^{4}$. Już we wstępie do konstytucji MOP, przyjętej 21 listopada 1919 r. ${ }^{5}$, proklamowano, że urzeczywistnienie zasady wolności zrzeszania się jest jednym z podstawowych warunków zapewniających pokój i powszechną harmonię na świecie 6 .

Powstanie MOP w 1919 r. było logicznym uwieńczeniem procesu rozwojowego, który zarysował się w na początku XIX w. i rozwijał się w drugiej połowie tego stule-

${ }^{3}$ F. Sokala, Komisja Pracy Konferencji Pokojowej w Paryżu 1919 r., Warszawa 1920, s. 37-39.

${ }^{4}$ Dz.U. z 1920 r. nr 35, poz. 200.

${ }^{5}$ Podczas pierwszej Konferencji Ogólnej w Waszyngtonie.

${ }^{6} \mathrm{~W}$ preambule do konstytucji MOP ustanowiono: „Zważywszy, że pokój powszechny i trwały może być zbudowany jedynie na zasadach sprawiedliwości społecznej; Zważywszy, że pewne warunki pracy są dla wielkiej liczby ludzi niesprawiedliwe, powodują nędzę i niedostatek, co rodzi niezadowolenie, zagrażające pokojowi i harmonii powszechnej, i zważywszy, że polepszenie powyższych warunków jest rzeczą pilną, na przykład, o ile dotyczy unormowania godzin pracy, [...] uznania zasady wolności zrzeszania się [...]; Zważywszy, że nieuwzględnienie przez któryś z narodów istotnie ludzkich warunków pracy stanowi przeszkodę dla wysiłków innych narodów, pragnących polepszenia losu robotników w ich własnych krajach; Wysokie Układające się strony, powodowane uczuciem sprawiedliwości i ludzkości, jak również chęcią zapewnienia trwałego pokoju świata, oraz mając na względzie osiagnięcie celów, wymienionych w tym wstępie, zgadzają się na następującą Konstytucję Międzynarodowej Organizacji Pracy”. Tekst źródłowy pochodzi ze strony internetowej: <www.mop.pl>, dostęp 10 IX 2017. 
cia, przyczynił się do utworzenia MOP wraz z zakończeniem I wojny światowej. Przesłanki, na podstawie których wysuwano postulat tworzenia międzynarodowych norm pracy, także w zakresie wolności zrzeszania się pracowników, były dwojakiego rodzaju. Używano argumentu ekonomicznego, zgodnie z którym jednolite międzynarodowe normy prawa pracy staną się środkiem obrony sytuacji krajów realizujących nową politykę społeczną przed konkurencją krajów niestosujących takich rozwiązań i mających $\mathrm{z}$ tego tytułu niższe koszty własne produkcji, a tym samym korzystniejszą sytuację na rynkach światowych. Tak sformułowany argument ,antykonkurencyjny” dominował w XIX w., ale z czasem ustępował przesłankom humanitarnym i socjalnym ${ }^{7}$. W XX w. przede wszystkim związki zawodowe domagały się, aby ochrona pracy i inne uprawnienia pracownicze były podnoszone we wszystkich krajach do poziomu osiagniętego w krajach najwyżej rozwiniętych, głównie w imię sprawiedliwości społecznej.

\section{SPECYFIKA AKTÓW PRAWNYCH MIĘDZYNARODOWEJ ORGANIZACJI PRACY}

Specyfiką wszystkich aktów przyjętych przez MOP było to, że w ich przygotowaniu brały bezpośredni udział związki zawodowe oraz organizacje pracodawców na równych prawach obok przedstawicieli rządów ${ }^{8}$. Podstawowymi dokumentami przyjmowanymi w ramach MOP były konwencje i zalecenia. W latach 1919-1939 uchwalono 67 konwencji i 66 zaleceń $^{9} \mathrm{Z}$ inicjatywą uchwalenia tych dokumentów mogło wystapić państwo członkowskie MOP, krajowa organizacja pracowników, krajowa organizacja pracodawców czy też organizacja międzynarodowa ${ }^{10}$. Nie miały one charakteru międzynarodowych źródeł prawa bezpośrednio negocjowanych (jak traktaty międzynarodowe) przez zainteresowane państwa ${ }^{11}$. Uchwalane były przez MOP większością 2/3 głosów delegatów reprezentujących rządy oraz działające w poszczególnych państwach członkowskich związki zawodowe i organizacje pra-

7 J. Rosner, Tendencje rozwojowe międzynarodowego prawa pracy, „Acta Universitatis Lodziensis. Folia Iuridica" 1981, t. 5, s. 22.

${ }^{8}$ Vide K. Walczak, Struktura Konwencji MOP na tle innych umów międzynarodowych, „Państwo i Prawo" 1996, z. 2, s. 56.

${ }^{9}$ B. Paździor, Tworzenie konwencji i zaleceń Międzynarodowej Organizacji Pracy, „Acta Universitatis Lodziensis. Folia Iuridica" 1981, t. 5, s. 63.

${ }^{10} \mathrm{~W}$ sprawie inicjatywy uchwałodawczej vide A. Suviranta, The role of the member states in the unification work of the International Labour Organization, Helsinki 1966, s. 28-35; W. Fronczak, Międzynarodowa Organizacja Pracy, Warszawa 1965, s. 129-138; B. Paździor, Wplyw Międzynarodowego Biura Pracy na konwencje i zalecenia Międzynarodowej Organizacji Pracy, Warszawa-Wrocław 1975, s. 38 -46; J. Białocerkiewicz, Wpływ Międzynarodowej Organizacji Pracy na ujednolicenie prawa pracy, Toruń 1981, s. 53-57.

${ }^{11}$ W sytuacji gdy w pracach przygotowawczych nad dokumentami brali udział nie tylko przedstawiciele rządów, ale również pracodawców i pracowników, jak również ze względu ma fakt, że konwencje obowiązują dopiero po ich ratyfikacji, niemożliwe stało się umieszczanie tradycyjnej intytulacji (określenie stron umowy). Jednak aby wskazać podmiot, który odpowiada za przygotowanie tekstu, wprowadzono konstrukcję, że jest nim Konferencja Ogólna MOP, podczas której uchwala się konwencję. Organem, który zwoływał sesję tej organizacji była Rada Administracyjna. W okresie dwudziestolecia międzywojennego dodawano informację o tym, że MOP jest częścią Ligi Narodów. Sesje tej organizacji odbywały się w Waszyngtonie 1919 r. oraz Genewie 1920-1939. Vide K. Walczak, Struktura Konwencji.., s. 56. 
codawców ${ }^{12}$. Dążenie do tego, żeby akty normatywne MOP mogły wpływać na prawo krajowe, widoczne już było w działaniach twórców tej organizacji. Jego wyrazem była propozycja wysunięta w czasie obrad Komisji MOP na konferencji pokojowej w Paryżu (1919 r.), aby konwencje uchwalane przez MOP miały moc wiążącą wobec jej członków. Jednak ze względu na suwerenność państw członkowskich, do których należała też Polska, przyjęto rozwiązanie kompromisowe, polegające na uchwalaniu konwencji podlegających ratyfikacji ${ }^{13}$.

Udział partnerów społecznych w pracach legislacyjnych MOP powodował, że konwencje i zalecenia, za którymi głosowali przedstawiciele władz państwa członkowskiego, organizacje pracodawców i związki zawodowe funkcjonujące w tym państwie, były szybciej wprowadzane w życie oraz staranniej i chętniej stosowane. Władze państw członkowskich były zobowiązane przedstawić uchwalone przez Międzynarodową Konferencję Pracy MOP dokumenty międzynarodowe organom ustawodawczym kompetentnym do stanowienia przepisów krajowych w celu ich ewentualnej ratyfika$\mathrm{cji}^{14}$. Jednak państwa członkowskie nie były obowiązane ratyfikować uchwalanych przez MOP dokumentów międzynarodowych ${ }^{15}$.

Obowiazzek wynikający z art. 19 pkt $5 \mathrm{~b}$ oraz pkt $6 \mathrm{~b}$ konstytucji MOP dotyczący przedstawiania konwencji i zaleceń władzom, do których kompetencji należy podjęcie stosownej akcji legislacyjnej, stanowił środek ułatwiający i gwarantujący ich wprowadzenie do porządku prawnego państw członkowskich. Czynność tę należało dokonać w ciagu roku od daty zamknięcia sesji Konferencji, na której dany akt został uchwalony. MOP była zainteresowana, aby w prezentacji tej nie pomijano parlamentu. W takim przypadku istniała możliwość publicznego przedyskutowania aktualnego stanu ustawodawstwa krajowego w danej sprawie i możliwości recypowania odnoszących się do niego norm $\mathrm{MOP}^{16}$.

Podstawowymi dokumentami uchwalanymi w ramach MOP od samego początku jej funkcjonowania były konwencje, które wiążą państwa członkowskie z chwilą ratyfikacji. Regulują one prawne aspekty administracji pracy, dobrobytu społecznego lub praw człowieka w pracy. Ich ratyfikacja powoduje podwójne zobowiązanie pań-

12 Konwencje i zalecenia są zaliczane do kategorii traktatów stanowionych przez organizację międzynarodową (treaty laws), a nie negocjowanych przez państwa członkowskie (treaty contracts). A.M. Świątkowski, Międzynarodowe prawo pracy, t. 1, Międzynarodowe publiczne prawo pracy, Warszawa 2008, s. 51.

${ }^{13}$ H. Zasztowt-Sukiennicka, Międzynarodowa Organizacja Pracy, Warszawa-Wilno 1929, s. 92-98.

14 Głównymi organami MOP są: Międzynarodowa Konferencja Pracy (zgromadzenie ogólne) zbierająca się co roku; Rada Administracyjna (rada wykonawcza); Międzynarodowe Biuro Pracy (stały sekretariat). Międzynarodowa Konferencja Pracy wybiera Radę Administracyjna, przyjmuje budżet MOP finansowany ze składek krajów członkowskich, ustanawia międzynarodowe standardy pracy, stanowi światowe forum do dyskusji problemów społecznych i problemów pracy. Każda delegacja krajowa składa się z dwóch delegatów rządowych, jednego delegata przedsiębiorców i jednego delegata pracowników. Delegaci przedsiębiorców i pracowników są niezależni; mogą oni — i często to czynią — nie zgadzać się ze swoimi rządami i między sobą.

15 M. Seweryński, Działalność Międzynarodowej Organizacji Pracy na rzecz ochrony praw człowieka, [w:] Ochrona praw człowieka w świecie, red. L. Wiśniewski, Bydgoszcz-Poznań 2000, s. 161-162.

${ }_{16}$ M. Seweryński, Wplyw konwencji i zaleceń Międzynarodowej Organizacji Pracy na prawo krajowe, „Acta Universitatis Lodziensis. Folia Iuridica” 1981, t. 5, s. 105. 
stwa członkowskiego: jest to zarówno formalna zgoda na stosowanie ustaleń konwencji, jak i wykazanie chęci akceptacji międzynarodowych środków nadzoru ${ }^{17}$. Jeżeli przedłożona konwencja nie została przez państwo ratyfikowana, to zobowiązane jest ono do składania MOP sprawozdania co do stanu swego ustawodawstwa i praktyki w sprawach stanowiących przedmiot konwencji. W sprawozdaniach tych państwo członkowskie wyjaśnia, w jakiej mierze ma zamiar wprowadzić postanowienia konwencji w przyszłości i za pomoca jakich środków prawnych, a także jakie trudności stoją na przeszkodzie ratyfikacji konwencji. Celem takiej procedury sprawozdawczej było wywarcie nacisku na państwa członkowskie MOP, w tym także i Polskę, żeby recypowały one normy uchwalone przez tę organizację.

Reasumując, mechanizm kontroli przewidziany w konstytucji MOP uchwalonej jeszcze w 1919 r. zakładał wzajemne uzupełnianie się dwóch metod. Pierwsza, oparta na sprawozdaniach dotyczących konwencji, ma charakter stały. Nie dotyczy ona zaleceń, które nie nakładały na państwa konkretnych obowiązków, a wskazywały jedynie na pożądane kierunki działania. Drugą metodę o charakterze nadzwyczajnym tworzą instytucje zażaleń i skarg. Zażalenia mogą być wnoszone przez organizacje zawodowe pracowników i pracodawców przeciwko państwu, które - ich zdaniem — nie zapewniło skutecznego przestrzegania ratyfikowanej konwencji. Skarga natomiast może być złożona przez jedno państwo członkowskie przeciwko innemu, któremu stawia się zarzut, że nie przestrzegało konwencji, którą ratyfikowało. Do złożenia skargi uprawnione jest tylko państwo, które ratyfikowało daną konwencję ${ }^{18}$.

\section{WPLYW NORM MIĘDZYNARODOWEJ ORGANIZACJI PRACY NA USTAWODAWSTWO POLSKIE DOTYCZĄCE WOLNOŚCI ZRZESZANIA SIĘ W ZWIĄZKI ZAWODOWE}

Wpływ norm stanowionych przez MOP na prawo krajowe jest widoczny wtedy, gdy powodują one ustanowienie przepisów nieistniejących wcześniej w danym państwie. Jego oddziaływanie może także polegać na modyfikacji norm istniejących. Często też recepcja standardów uchwalonych przez MOP nie pociaga za sobą żadnych zmian w ustawodawstwie krajowym dlatego, że dane państwo nie poczyniło kroków umożliwiających ich wejście w życie lub już wcześniej uchwaliło prawo odpowiadające ratyfikowanej konwencji. W tym drugim przypadku można jednak mówić o wpływie norm MOP na prawo krajowe, ponieważ podporządkowanie się im umacnia gwarancje respektowania tego prawa, zwłaszcza przez poddanie się kontroli MOP. Tym

${ }^{17} \mathrm{~W}$ okresie 20-lecia międzywojennego obowiązkowej rejestracji ratyfikacji konwencji MOP dokonywał sekretarz generalny Ligi Narodów. Istotną rolę w rozstrzyganiu wątpliwości odegrał Stały Trybunał Sprawiedliwości Międzynarodowej, który w kilku orzeczeniach (wydanych w latach 1922-1932) zajął stanowisko, że MOP może obejmować swoją działalnością normatywną nie tylko przemysł, lecz także rolnictwo, nie tylko pracowników najemnych, lecz także osoby wykonujące pracę na innych podstawach prawnych oraz że normy MOP stosuje się nie tylko do robotników, lecz także do osób wykonujących pracę inną niż fizyczna, do kobiet i dzieci oraz do cudzoziemskich pracowników. Zob. M. Seweryński, Działalność Międzynarodowej Organizacji Pracy na rzecz ochrony praw czlowieka, [w:] Ochrona praw czlowieka w świecie..., s. 152.

${ }_{18}$ A. Gubiński, Kontrola przestrzegania konwencji i zaleceń Międzynarodowej Organizacji Pracy, „Acta Universitatis Lodziensis. Folia Iuridica” 1981, t. 5, s. 82. 
samym uniemożliwia się dokonanie zmiany prawa krajowego na gorsze z punktu widzenia interesów pracowniczych. Ten przypadek odzwierciedla w pewnym sensie sytuację w Polsce po odzyskaniu niepodległości i wydaniu 8 lutego 1919 r. przez Tymczasowego Naczelnika Państwa dekretu w przedmiocie tymczasowych przepisów o pracowniczych związkach zawodowych ${ }^{19}$.

Należy przypomnieć, że 11 kwietnia 1919 r. przyjęto dokument stanowiący źródło przyszłej konstytucji MOP, który został włączony do rozdziału XIII Traktatu Wersalskiego. Zgodnie z art. 427 strony traktatu uznały, że ,[...] różnice klimatu, obyczajów i zwyczajów, warunków ekonomicznych i tradycji przemysłowych czynią trudnem do osiagnięcia natychmiastowe i zupełnie ujednostajnienie warunków pracy. Są jednak przeświadczone, że praca nie powinna być uważana po prostu za przedmiot handlu i sądzą że pewne metody i zasady reglamentacji warunków pracy, powinny by postarać się zastosować wszystkie zrzeszenia przemysłowe, o ile tylko pozwolą na to specjalne warunki, w jakich one się znajdują. Z pomiędzy tych metod i zasad Wysokie Układające się Strony uważają za szczególnie ważne i pilne [...] prawo zrzeszania się pracowników, jak i przedsiębiorców dla celów przez prawo niewzbronionych"20. Natomiast we wstępie do konstytucji MOP proklamowano, że urzeczywistnienie zasady wolności zrzeszania się jest jednym z podstawowych warunków zapewniających pokój i powszechną harmonię na świecie ${ }^{21}$.

W chwili odrodzenia się państwa polskiego obowiązywały na jego terenie ustawy pozaborcze ${ }^{22}$, jednak niemal od początku istnienia Rzeczypospolitej Polskiej, zgodnie z później przyjętymi normami zawartymi w konstytucji MOP, wprowadzono prawo zrzeszania się. Dekret w przedmiocie tymczasowych przepisów o pracowniczych związkach zawodowych został uchwalony na dwa dni przed rozpoczęciem działalności przez Sejm Ustawodawczy, który 10 lutego 1919 r. zatwierdził ten dekret. Był to w tamtym okresie najbardziej postępowy akt normatywny dotyczący związków zawodowych, który odpowiadał już przyszłym standardom nakreślonym przez MOP, zgodny procesem rozwojowym państw, który przybrał na sile w drugiej połowie XIX w. Charakteryzował się on m.in. ułatwieniami w zakresie zakładania związków zawodowych oraz uniwersalnym ujęciem celów i zadań związków zawodowych, uchylił wszystkie pozaborcze przepisy o związkach zawodowych oraz zobowiązał istniejące związki zawodowe do uwzględnienia jego przepisów (art. 16 dekretu). Zgodnie z dekretem za związki zawodowe uznano związki pracownicze, których zadaniem była obrona i popieranie interesów ekonomicznych i kulturalnych pracowników danej gałęzi pracy lub gałęzi pokrewnych albo podobnych ${ }^{23}$. Legalizacja związku odbywała

19 Dz.Pr.P.P. z 1919 r. nr 15, poz. 209.

${ }^{20}$ Dz.U. z 1920 r. nr 35, poz. 200.

${ }^{21}$ A. Malanowski, O zasadzie wolności zwiazkowej w aktualnym stanie prawnym, Warszawa 1983, s. 4.

22 Vide szerzej E. Smoktunowicz, Prawo zrzeszania się w Polsce, Warszawa 1992, s. 21-26.

${ }^{23}$ Przepisom dekretu nie podlegały zrzeszenia pracowników instytucji państwowych. Dekret zawierał postanowienie, że statuty takich organizacji są zatwierdzane przez Radę Ministrów. Na mocy ustawy z dnia 3 grudnia 1924 r. w przedmiocie zmiany niektórych postanowień o pracowniczych związkach zawodowych, względnie o stowarzyszeniach i związkach, a mianowicie postanowień, dotyczących zrzeszania się pracowników państwowych (Dz.U. z 1924 r. nr 114, poz. 1012) zrzeszenia pracowników państwowych nie podlegały 
się na podstawie jego rejestracji w obwodowym inspektoracie pracy. Jednak gdy statut związku przewidywał prawo zakładania oddziałów na obszarze całego kraju, podlegał on rejestracji w Głównym Inspektoracie Pracy. Przewidziana w dekrecie rejestracja organizacji związkowej uregulowana została w okólniku nr 5 Głównego Inspektora Pracy ${ }^{24}$. Przez zarejestrowanie związek zawodowy uzyskiwał osobowość prawną wraz z przywilejem nabywania nieruchomości, otrzymywania zapisów i darowizn bez żadnych ograniczeń. Ponadto mógł zawierać układy zbiorowe pracy oraz uczestniczyć w charakterze strony w procesie cywilnym. Wniosek o zarejestrowanie organizacji związkowej musiał być podpisany przez co najmniej trzech członków założycieli. Dekret zawierał wymóg, aby do wniosku dołączyć projekt statutu w dwóch egzemplarzach, który powinien regulować istotne z punktu widzenia funkcjonowania związku zawodowego kwestie, określone w przepisach o pracowniczych związkach zawodowych ${ }^{25}$. Odmowa rejestracji mogła nastapić tylko w dwóch przypadkach: gdy statut związku nie czynił zadość wymaganiom przewidzianym w dekrecie lub był niezgodny z powszechnie obowiązującym prawem ${ }^{26}$. Na decyzję odmowną przysługiwała skarga do sądu powszechnego. Dekret stanowił, że w przypadku 20-dniowej zwłoki decyzyjnej właściwego inspektora pracy, liczonej od dnia złożenia podania, związek zawodowy uważany był za zarejestrowany.

Na mocy nowych przepisów o pracowniczych związkach zawodowych organ rejestracyjny nie uzyskał żadnych uprawnień nadzorczych nad związkami zawodowymi, a jedynie ograniczone uprawnienia kontrolne, które sprowadzały się do otrzymywania od związków sprawozdań składanych przez nie na ogólnych zebraniach. Nadzór nad zwiazkami, ograniczony tylko do przeciwdziałania popełnianiu przez nie przestępstw lub wykroczeń, powierzono sądom okręgowym. W przypadku działalności związku wypełniającej znamiona popełnienia czynu zabronionego, sąd okręgowy mógł nałożyć grzywnę na winnych bądź zawiesić na określony czas działalność związku albo związek rozwiązaće 27 .

postanowieniom dekretu z 8 lutego 1919 r., lecz przepisom dekretu o stowarzyszeniach z dnia 3 stycznia 1919 r. (Dz.Pr.P.P. nr 3, poz. 88) lub rozporządzeniu Komisarza Generalnego Ziem Wschodnich z dnia 25 września 1919 r. o stowarzyszeniach i związkach (Dz.Urz. Zarz. Cyw. Ziem Wschodnich z 1919 r. nr 25, poz. 255).

24 „Biuletyn Ministerstwa Pracy i Opieki Społecznej” z 1919 r., nr 4, s. 34.

${ }^{25} \mathrm{~W}$ art. 5 dekretu określono, że statut powinien zawierać następujące dane: nazwę, teren działalności, siedzibę związku; zadania i formy działalności związku; warunki przyjmowania członków i wykluczania; sposób pobierania składek członkowskich; prawa i obowiązki władz związku; tworzenie, termin i formy urzędowania tych władz; rozporządzanie majątkiem związkowym; warunki likwidacji związku.

26 Najwyższy Trybunał Administracyjny uznał w orzeczeniu nr 886, że pozbawiona jest podstaw prawnych odmowa rejestracji, jeżeli inspektor pracy nie wskazał, na jakich postanowieniach projektu statutu związku zawodowego opiera swe przypuszczenie co do jego przewidywalnej działalności niezgodnej z prawem. Vide J. Bloch, Kodeks pracy, Warszawa 1936, s. 643.

27 Zgodnie z art. 14 dekretu z 1919 r. ,komplet karny” sądu okręgowego orzekał na wniosek władzy administracyjnej o rozwiązaniu związku zawodowego „,w razie skierowania działalności związku do zadań stanowiących przestępstwo lub wykroczenie". W dekrecie nie określono trybu postępowania przy orzekaniu o rozwiązaniu związku zawodowego ani też zakresu sądowej kontroli nad działalnością związków zawodowych. Kwestię tę poruszał w swoich orzeczeniach Sąd Najwyższy. Vide orzeczenia SN z: 13 listopada 1923 r. (OSN 301/23); 22 maja 1924 r. (OSN 88/24); 23 kwietnia 1925 r. (OSN 149/25). 
Wolność koalicji znalazła swoje miejsce również w konstytucji z 17 marca z $1921 \mathrm{r}^{28} \mathrm{~W}$ kwestii związków zawodowych stanowiła ona jedynie w art. 108, że obywatele mają prawo koalicji, zgromadzenia się i zawiązywania stowarzyszeń i związków. W ramach tej regulacji uwagę zwraca brak wyraźnego wyodrębnienia wolności zrzeszania się w związkach zawodowych (wolności koalicji). Unormowania umieszczane $\mathrm{w}$ aktach prawnych rangi ustaw zasadniczych w okresie międzywojennym poświęcały kwestii wolności zrzeszania się w związkach zawodowych (zwanej inaczej wolnością koalicji) niewiele miejsca.

Pewnym odejściem od ducha norm stanowionych przez MOP były przepisy uchwalonej 23 kwietnia $1935 \mathrm{r}$. konstytucji ${ }^{29}$, które w ogóle nie posługiwały się pojęciem prawa koalicji, zadowalając się wyłącznie klauzulą ogólną sformułowaną w art. 5 ust. 2, że ,[...] zapewnia się obywatelom możliwość rozwoju ich wolności osobistych, oraz wolności zgromadzeń, słowa i zrzeszeń". Związkiem zawodowym mogło być każde stowarzyszenie zarówno pracowników, jak i pracodawców oparte na przynależności do pewnego zawodu ${ }^{30}$. Jednocześnie w ust. 3 tegoż przepisu wprowadzono zastrzeżenie, że prawa, w tym także wolność zrzeszania się, nie przysługują bezwarunkowo, gdyż ich granicą jest dobro powszechne ${ }^{31}$. Na początku lat trzydziestych nastapił zwrot również w sytuacji prawnej związków zawodowych. Jeżeli chodzi o sytuację ruchu związkowego wyrażał się on między innymi zwiększonym wpływem władz na funkcjonowanie związków zawodowych poprzez poddanie ich bardziej rygorystycznej i wszechstronnej kontroli ze strony organów państwowych ${ }^{32}$. Owocem reformy prawa związkowego były odpowiednie przepisy rozporządzenia Prezydenta Rzeczypospolitej z dnia 27 października 1932 r. - Prawo o stowarzyszeniach ${ }^{33}$. Fakt nadmiernego zróżnicowania sytuacji prawnej związków zawodowych, działających w poszczególnych dzielnicach Polski, stał się formalnym argumentem za unifikacją przepisów o związkach zawodowych ${ }^{34}$.

${ }^{28}$ Dz.U. z 1921 r. nr 44, poz. 267.

29 Dz.U. z 1935 r. nr 30, poz. 227.

30 S.M. Grzybowski, Pracownicze zwiąki zawodowe. Droga rozwoju, Kraków 1948, s. 11.

31 J. Mazurkiewicz, Zagadnienie pracy w konstytucjach powojennych, Lublin 1926.

32 Vide J. Wengierow, Prawo pracy w okresie petnomocnictw roku 1932, „Praca i Opieka Społeczna” 1932, nr 4, s. 349.

33 Dz.U. z 1932 r. nr 94, poz. 808.

${ }_{34}$ Dekret z 8 lutego 1919 r. obowiązywał w województwach warszawskim, łódzkim, kieleckim, lubelskim i w zachodniej części województwa białostockiego, co stawiało województwa centralne w sytuacji uprzywilejowanej wobec województw zachodnich, południowych i wschodnich, które nie posiadały odrębnego ustawodawstwa o związkach zawodowych. Nowe prawo o stowarzyszeniach, mimo że zawierało stwierdzenie, że związki zawodowe będące przedmiotem osobnych przepisów nie podlegają uregulowaniom niniejszego rozporządzenia, to jednak zawarte w nim wyliczenie tych przepisów prawa o stowarzyszeniach, które bezpośrednio odnosiły się do wszystkich związków zawodowych, bez względu na to, na jakim terenie działały i jakim podlegały przepisom, przeczyło tej wstępnej deklaracji. Skutkiem takiej regulacji było poddanie istniejących związków zawodowych dwóm odrębnym aktom prawnym. Te z nich, które działały na terenie wymienionych wyżej pięciu województw centralnych, nadal podlegały przepisom dekretu z 8 lutego 1919 r. oraz tym regulacjom prawa o stowarzyszeniach, które odnosiły się do wszystkich organizacji zawodowych, bez względu na obszar ich działalności. Na pozostałym terytorium RP związki zawodowe podlegały całkowicie prawu o stowarzyszeniach, łącznie z tymi, które powstały już po wejściu w życie rozporządzenia Prezydenta Rzeczypospolitej z dnia 27 października 1932 r. Vide J. Wengierow, Prawo..., s. 349. 
To rozporządzenie znacznie zaostrzało przesłanki prawne zawieszenia działalności lub rozwiązania związku zawodowego. Przepisy dekretu z 8 lutego 1919 r. przewidywały możliwość zawieszenia działalności lub rozwiązania organizacji związkowej, jeżeli działalność ta była przestępstwem lub wykroczeniem. Prawo o stowarzyszeniach dopuszczało tego typu sankcje także w przypadku, gdy działalność związku zawodowego zagrażała bezpieczeństwu, spokojowi lub porządkowi publicznemu. Ponadto wyraźnie akcentowało fakt powierzenia bezpośredniego nadzoru nad związkami zawodowymi władzom administracji ogólnej35. Znacząco ograniczona została wszelka tajemnica posiedzeń i uchwał związkowych. Władze administracji ogólnej szczebla powiatowego mogły według własnego uznania zażądać od związku dostarczenia odpisu protokołu posiedzenia lub powziętej uchwały. Ponadto mogły przeglądać w lokalach związkowych prowadzone akta, księgi i posiadane dokumenty, jak również sporządzać z nich notatki, odpisy i wyciągi, a także wzywać zarząd związku zawodowego do okazania posiadanych dokumentów w oznaczonym terminie $^{36}$.

\section{KONWENCJE CHRONIĄCE WOLNOŚĆ PRACOWNIKÓW DO ZRZESZANIA SIĘ RATYFIKOWANE PRZEZ POLSKE}

Największe możliwości oddziaływania norm MOP na prawo krajowe stwarzała ratyfikacja konwencji. Jako typowy sposób recypowania międzynarodowego prawa pracy dawała możliwość formalnego przekształcenia jego przepisów w źródło prawa wewnętrznego i zagwarantowania ich realizacji. MOP od początku swojego istnienia zajmowała się kwestią wolności zrzeszania się. W preambule do konstytucji MOP uznanie zasady wolności zrzeszania się zaliczono do tych środków, które stanowią niezbędny warunek polepszenia warunków pracy i życia, osiagnięcie powszechnego i trwałego pokoju opartego na zasadach sprawiedliwości społecznej. Konstytucja MOP jest aktem, którego państwa członkowskie zobowiązały się przestrzegać w momencie wstąpienia do organizacji.

W nowym ładzie społeczno-politycznym w Europie po zakończonej I wojny światowej należało znaleźć miejsce także dla zorganizowanego ruchu zawodowego. Jednak kwestia wolności zrzeszania się w związki zawodowe okazała się na tyle kontrowersyjna, że mimo znacznych wysiłków nie doszło do uchwalenia aktu, który w sposób kompleksowy zagwarantowałby pracownikom swobodę zrzeszania się ${ }^{37}$. Dlatego też pierwsza umowa międzynarodowa MOP, uchwalona 25 października 1921 r. na trzeciej sesji Konferencji Ogólnej MOP, Konwencja nr 11 o prawie zrzeszania się i koalicji pracow-

${ }^{35}$ Art. 11 ust. 2 prawa o stowarzyszeniach stanowił, że związki zawodowe miały obowiązek dostarczać powiatowej władzy administracji ogólnej miejsca ich siedziby na jej żądanie danych co do składu swego zarządu oraz miały podlegać przepisom art. 15 i 17, z tym że przez bezpośrednią władzę nadzorczą o której mowa w art. 15, należy rozumieć powiatową władzę administracji ogólnej.

${ }^{36}$ Art. 15 rozporządzenia Prezydenta Rzeczypospolitej z dnia 27 października 1932 r. — Prawo o stowarzyszeniach.

${ }_{37}$ Vide A. Zdanowski, Międzynarodówka zawodowa w świetle uchwat, „Robotniczy Przegląd Gospodarczy" 1926, nr 9, s. 202. 
ników rolnych ${ }^{38}$, ratyfikowana przez Polskę, dotyczyła prawa organizowania się. Zgodnie z art. 1 tej Konwencji, każdy członek MOP, ratyfikujący niniejszą Konwencję, zobowiązał się zapewnić wszystkim osobom zatrudnionym w rolnictwie takie same prawa zrzeszania się i koalicji, z jakich korzystają pracownicy przemysłowi. Ponadto zobowiązano państwa członkowskie do uchylenia wszelkich postanowień ustawodawczych lub innych, wydawanych przez pracodawców zatrudniających robotników rolnych, ograniczających ich prawo do zakładania i przystępowania do utworzonych organizacji. Konwencja $\mathrm{nr} 11$ nakładała obowiązek stosowania jednolitych standardów w rolnictwie i przemyśle w sprawach dotyczących prawa pracowników do zrzeszania się ${ }^{39}$. Każde państwo członkowskie MOP, ratyfikujące niniejszą Konwencję, zobowiązało się stosować ją w swoich koloniach, posiadłościach i protektoratach, zgodnie z postanowieniami art. 421 traktatu wersalskiego ${ }^{40}$. Natomiast art. 8 Konwencji nakładał na Radę Administracyjną MOP obowiązek składania sprawozdania ze stosowania konwencji co najmniej raz na 10 lat na Ogólnej Konferencji. Ratyfikacja tego dokumentu przez RP potwierdzała istniejący stan prawny, gdyż robotnicy rolni po odzyskaniu niepodległości mieli już prawo zakładania organizacji zawodowych, które funkcjonowały na terenie całego kraju.

Trudnością w stosowaniu Konwencji nr 11 był fakt braku międzynarodowych standardów, które określałyby zasady zrzeszania się w organizacjach związkowych pracowników przemysłu ${ }^{41}$. Stąd też w 1923 r. Rada Administracyjna podjęła uchwałę o przeprowadzeniu studiów nad przestrzeganiem przez państwa członkowskie, w tym również i Polskę, gwarantowanej konstytucją MOP zasady wolności zrzeszania się ${ }^{42}$. Na podstawie wyników przeprowadzonych badań został przygotowany i przedstawiony na sesji Konferencji Ogólnej MOP w 1927 r. projekt konwencji dotyczącej prawa zrzeszania się.

Zgodnie z zasadą przyjętą w 1926 r. MOP, zajmując się określoną sprawą po raz pierwszy, mogła ograniczyć się tylko do ogólnego omówienia problemu i uchwalenia kwestionariusza adresowanego do państw członkowskich. Międzynarodowe Biuro Pracy (stały sekretariat MOP) w opracowanym projekcie ankiety proponowało, aby wolność zrzeszania się w związki zawodowe lub prowadzenia akcji związkowych mogła być ograniczona tylko ze względu na ,porządek publiczny”. Wniosek ten jednak upadł. Wstępną aprobatę uzyskała sprawa tzw. formalności prawnych przy powstaniu lub re-

${ }^{38}$ Konwencja o prawie zrzeszania się i koalicji pracowników rolnych, przyjęta jako projekt 12 listopada 1921 r. w Genewie na Ogólnej Konferencji MOP Ligi Narodów (ratyfikowana przez Polskę w 1924 r.), Dz.U. z 1925 r. nr 54, poz. 378.

39 N. Valticos, G. von Potobsky, International Labour Law, Deventer 1995, s. 92.

40 Zgodnie z art. 421 traktatu wersalskiego członkowie zostali zobowiązani do stosowania konwencji, do których przystapili zgodnie z postanowieniami traktatu, do tych swoich kolonii lub posiadłości oraz krajów, znajdujących się pod ich protektoratem.

41 N. Valticos, International Labour Law, Deventer 1979, s. 80. Vide K. Walczak, Zbiorowe prawo pracy. Aspekty prawa międzynarodowego, europejskiego i polskiego, Warszawa 2004, s. 8.

${ }^{42}$ Rezultaty badań porównawczych zostały opublikowane w pięciu tomach. Vide A.M. Świątkowski, Konwencja $n r 87$ MOP dotyczaca wolności zrzeszania się pracowników w zwiazkach zawodowych, [w:] Z zagadnień współczesnego prawa pracy. Księga jubileuszowa Profesora Henryka Lewandowskiego, red. Z. Góral, Warszawa 2009, s. 220. 
jestracji związków zawodowych. Jednak w latach dwudziestych XX w. w niektórych krajach powstanie związku zawodowego nie wymagało w zasadzie uprzedniego dokonania formalności prawnych. Wskutek zdecydowanego sprzeciwu przedstawicieli związków zawodowych powyższe kwestie wykreślono z kwestionariusza ${ }^{43}$.

W trakcie debaty na sesji Konferencji Ogólnej MOP w 1927 r. zgłoszone zostały dwie poprawki, które dotyczyły objęcia ochroną prawną tzw. negatywnej wolności zrzeszania się tych pracowników, którzy nie chcą należeć do związków zawodowych oraz uzależniały możliwość uczynienia użytku z prawa do tworzenia i przystępowania do istniejących organizacji związkowych od przestrzegania obowiązujących przepisów w państwach członkowskich. W przypadku Polski chodziło głównie o dekret w przedmiocie tymczasowych przepisów o pracowniczych związkach zawodowych wydany przez Tymczasowego Naczelnika Państwa 8 lutego 1919 r. ${ }^{44}$ Przedstawiciele pracowników obawiali się, że powyższy warunek może spowodować uzależnienie korzystania z pozytywnego uprawnienia do tworzenia związków zawodowych od udzielenia przez władze państwowe zezwolenia na założenie związku zawodowego. Powyższe obawy sprawiły, że projekt konwencji dotyczącej prawa zrzeszania się nie został przyjęty.

Problem, którego nie byli w stanie rozstrzygnąć delegaci na sesję Konferencji Ogólnej MOP, dotyczył związków między wolnościami, z jakich korzystaja jednostki, a wolnością zrzeszania się, która przysługuje grupom pracowników. W rzeczywistości problemem była tzw. negatywna wolność związkowa, która wyrażała się w zagwarantowaniu prawa niewstępowania do związków zawodowych tym pracownikom, którzy nie zamierzali korzystać z uprawnienia do zrzeszania się $\mathrm{w}$ organizacjach związkowych ${ }^{45}$.

Kolejna kwestia związana z projektem konwencji w sprawie wolności zrzeszania się dotyczyła przyznania związkom zawodowym uprawnienia do prowadzenia działalności w jakikolwiek sposób niekolidujący z interesami społeczności. Zdaniem delegatów pracowników, samo istnienie związku zawodowego świadczyło o występowaniu partykularnych interesów, które mogły być sprzeczne z interesami szerszej społeczności ${ }^{46}$. Mimo że sformułowanie odnoszące się do interesu społecznego zostało odrzucone przez Konferencję Ogólną, delegaci pracowników głosowali przeciwko wprowadzeniu projektu konwencji do porządku obrad kolejnej, 31. sesji Konferencji Ogólnej MOP. Z uwagi na stanowisko partnerów społecznych upadła próba uchwalenia międzynarodowego standardu dotyczącego wolności zrzeszania się w związkach zawodowych ${ }^{47}$.

Ochrony praw związków zawodowych pośrednio dotyczyły inne konwencje uchwalone w okresie międzywojennym przez MOP, które jednak nie zostały ratyfikowane

${ }^{43}$ B. Ziemięcki, Międzynarodowa Konferencja Pracy, „Robotniczy Przegląd Gospodarczy” 1927, nr 7, s. 145.

44 Dz. Pr. P.P. z 1919 r. nr 15, poz. 209.

${ }^{45}$ A.M. Świątkowski, Konwencja..., s. 221.

46 Vide Proceedings, International Labour Conference, 30th Session, 1927, s. 281.

${ }^{47}$ Przedstawiciele pracowników uważali, że uchwalenie konwencji w proponowanej wersji umożliwiłoby władzom państw członkowskich ograniczenie swobodnej działalności ruchu związkowego. Natomiast delegaci pracodawców nie chcieli głosować nad tekstem projektu konwencji, przyjęciu którego sprzeciwiali się przedstawiciele pracowników. Ibidem, s. 386. 
przez Polskę. Konwencja nr 44 z 1934 r. dotycząca zapewnienia bezrobotnym (nie z własnej winy) odszkodowania lub zasiłków, w art. 10 zawierała zasadę, że bezrobotny traci prawo do zasiłku lub zapomóg, jeżeli odmówi przyjęcia odpowiadającego mu zatrudnienia ${ }^{48}$. W tym artykule stwierdzono jednak, że nie może być traktowane jako odpowiednie miejsce pracy to, które jest zwolnione w związku ze wstrzymaniem pracy wskutek sporu zbiorowego. Przyczyną braku ratyfikacji przez Polskę tej konwencji był fakt uchwalenia ustawy z dnia 18 lipca 1924 r. o zabezpieczeniu na wypadek bezrobocia $^{49}$, która w zakresie prawa do zasiłku w wypadku odmowy podjęcia pracy w zakładzie objętym strajkiem pokrywała się z przedmiotowym przepisem Konwencji nr 44 . Nie została ratyfikowana przez Polskę także Konwencja nr 97 z 1939 r. dotycząca emigrantów. Art. 6 ust. 1 lit. a pkt 11 tego dokumentu zawierał zobowiązanie państwa członkowskiego przyjmującego emigrantów zarobkowych do traktowania ich na równi z własnymi obywatelami, m.in. w zakresie przynależności do organizacji związkowych.

Godnym odnotowania jest fakt podjęcia przez Radę Administracyjną MOP w 1932 r. kolejnej próby sformułowania międzynarodowego standardu wolności związkowej. W tym celu został powołany Komitet Wolności Związkowych. W dokumencie przygotowanym przez Komitet stwierdzono, że koniecznym warunkiem przestrzegania wolności zrzeszania się pracowników jest zagwarantowanie prawa tworzenia związków zawodowych bez konieczności uzyskania zezwolenia oraz zapewnienie organizacjom związkowym swobody działania bez administracyjnego nadzoru i kontroli ze strony organów państwa członkowskiego. Komitet stwierdził, że organizacje związkowe są obowiązane przestrzegać porządku prawnego ${ }^{50}$. Niestety wybuch II wojny światowej przerwał prace nad drugim projektem konwencji, która w sposób całościowy dotyczyła wolności zrzeszania się w związki zawodowe ${ }^{51}$.

\section{PODSUMOWANIE}

Analizując przedstawione wcześniej regulacje MOP, należy stwierdzić, że miały one charakter kompleksowy i stanowiły wzór dla krajów o różnych systemach rządów. Wolność koalicji zyskała w sferze normatywnej wiele gwarancji. Za normę prawną uznawano postanowienie zawarte w konstytucji MOP, wyrażające zasadę wolności zrzeszania się, zaś dokumenty MOP dotyczące tej wolności miały szczególne znaczenie dla pracowników jako podstawowy punkt obrony ich interesów. O ich roli i znaczeniu dobitnie świadczył fakt, że w większości publikacji naukowych konstytucja oraz konwencje MOP wymieniane są jako główne punkty odniesienia do oceny prawidłowości uregulowania poszczególnych instytucji związanych z wolnością zrzeszania się w związki zawodowe ${ }^{52}$.

${ }^{48}$ Konwencje MOP nie ratyfikowane przez Polske, cz. I, Warszawa 1970, s. 56.

49 Dz.U. z 1924 r. nr 67, poz. 650.

${ }^{50}$ Raport VII, Freedom of Association and Industrial Relations, International Labour Conference, 30th Session, 1947, s. 18.

${ }_{51}$ A.M. Świątkowski, Konwencja.., s. 222.

${ }^{52}$ L. Florek, Znaczenie umów międzynarodowych w prawie polskim, [w:] Prawo pracy u progu XXI wieku. Stare problemy i wyzwania wspótczesności: materiały z XIII Ogólnopolskiego Zjazdu Katedr 
Normy ustanawiane przez MOP wywarły również wpływ na polskie prawo w zakresie wolności związkowych. Stało się to poprzez zobowiązania wynikające z ratyfikacji konwencji, jak i przez stwarzanie nieformalnych nacisków w dostosowaniu prawa wewnętrznego do międzynarodowych wzorców ${ }^{53}$. Istotne znaczenie miał też tryb stanowienia norm w ramach MOP, który wyrażał się w szczególnym mechanizmie funkcjonowania tej organizacji, niemający precedensu w innych organizacjach. Istotną jego cechą był przyjęty we wszystkich ogniwach tego mechanizmu system trójstronnej reprezentacji krajów członkowskich przez przedstawicieli rządów, organizacji pracodawców i pracowników. Stanowi to odbicie układu sił decydujących o kształcie stosunków pracy oraz o kierunkach rozwoju prawa pracy w poszczególnych krajach, w tym także i w Polsce.

\section{BIBLIOGRAFIA}

ŹRÓDŁA

Proceedings, International Labour Conference, 30th Session, 1927.

Raport VII, Freedom of Association and Industrial Relations, International Labour Conference, 30th Session, 1947.

PIŚMIENNICTWO

Betten L., International Labour Law. Selected Issues, Kluwer, Deventer-Boston 1993.

Białocerkiewicz J., Wpływ Międzynarodowej Organizacji Pracy na ujednolicenie prawa pracy, Wydawnictwo Uniwersytetu Mikołaja Kopernika, Torun 1981.

„Biuletyn Ministerstwa Pracy i Opieki Społecznej’ 1919, nr 4.

Bloch J., Kodeks pracy, Dom Książki Polskiej, Warszawa 1936.

Florek L., Znaczenie umów międzynarodowych w prawie polskim, [w:] Prawo pracy u progu XXI wieku. Stare problemy i wyzwania wspótczesności: materiaty z XIII Ogólnopolskiego Zjazdu Katedr i Zakładów Prawa Pracy, Białystok 21-22 września 2001 r., Wydawnictwo Uniwersytetu w Białymstoku, Białystok 2001.

Florek L., Seweryński M., Międzynarodowe prawo pracy, Instytut Wydawniczy Związków Zawodowych, Warszawa 1988.

Follows J., Antecedents of the International Labour Organization, Clarendon Press, Oxford 1951.

Fronczak W., Międzynarodowa Organizacja Pracy, Wydawnictwo Związku Centralnego Rady Związków Zawodowych, Warszawa 1965.

Grzybowski S.M., Pracownicze zwiazki zawodowe. Droga rozwoju, Czytelnik, Kraków 1948.

Gubiński A., Kontrola przestrzegania konwencji i zaleceń Międzynarodowej Organizacji Pra$c y$, ,Acta Universitatis Lodziensis. Folia Iuridica” 1981, t. 5.

Konwencje Międzynarodowej Organizacji Pracy nie ratyfikowane przez Polske, cz. I, Warszawa 1970.

i Zakladów Prawa Pracy, Bialystok 21-22 września 2001 r., Wydawnictwo Uniwersytetu w Białymstoku, Białystok 2001, s. 39.

${ }_{53}$ W. Szubert, Problemy międzynarodowego prawa pracy, „Acta Universitatis Lodziensis. Folia Iuridica" 1981 , t. 5 , s. 5 . 
Malanowski A., O zasadzie wolności zwiqzkowej w aktualnym stanie prawnym, Wydawnictwo CDN, Warszawa 1983.

Mazurkiewicz J., Zagadnienie pracy w konstytucjach powojennych, Katolicki Uniwersytet Lubelski, Lublin 1926.

Paździor B., Wpływ Międzynarodowego Biura Pracy na konwencje i zalecenia Międzynarodowej Organizacji Pracy, Państwowe Wydawnictwo Naukowe, Warszawa-Wrocław 1975.

Paździor B., Tworzenie konwencji i zaleceń Międzynarodowej Organizacji Pracy, „Acta Universitatis Lodziensis. Folia Iuridica" 1981, t. 5.

Rosner J., Tendencje rozwojowe międzynarodowego prawa pracy, „Acta Universitatis Lodziensis. Folia Iuridica" 1981, t. 5.

Seweryński M., Działalność Międzynarodowej Organizacji Pracy na rzecz ochrony praw człowieka, [w:] Ochrona praw człowieka w świecie, red. L. Wiśniewski, Oficyna Wydawnicza „Branta”, Bydgoszcz-Poznań 2000.

Seweryński M., Wplyw konwencji i zaleceń Międzynarodowej Organizacji Pracy na prawo krajowe, „Acta Universitatis Lodziensis. Folia Iuridica” 1981, t. 5.

Smoktunowicz E., Prawo zrzeszania się w Polsce, Wydawnictwo Naukowe PWN, Warszawa 1992.

Sokala F., Komisja Pracy Konferencji Pokojowej w Paryżu 1919 r., Ministerstwo Pracy i Opieki Społecznej, Warszawa 1920.

Suviranta A., The Role of the Member States in the Unification Work of the International

Labour Organization, Institutum Jurisprudentiae Comparativae Universitatis Helsin-

giensis, Helsinki 1966.

Szubert W., Problemy międzynarodowego prawa pracy, „Acta Universitatis Lodziensis. Folia Iuridica" 1981, t. 5.

Świątkowski A.M., Konwencja nr 87 MOP dotyczaca wolności zrzeszania się pracowników w zwiazkach zawodowych, [w:] Z zagadnień współczesnego prawa pracy. Księga jubileuszowa Profesora Henryka Lewandowskiego, red. Z. Góral, Wolters Kluwer, Warszawa 2009.

Świątkowski A.M., Międzynarodowe prawo pracy, t. 1, Międzynarodowe publiczne prawo pracy, C.H. Beck, Warszawa 2008.

Walczak K., Struktura Konwencji MOP na tle innych umów międzynarodowych, „Państwo i Prawo" 1996, z. 2.

Walczak K., Zbiorowe prawo pracy. Aspekty prawa międzynarodowego, europejskiego i polskiego, C.H. Beck, Warszawa 2004.

Wengierow J., Prawo pracy w okresie petnomocnictw roku 1932, „Praca i Opieka Społeczna” $1932, \mathrm{nr} 4$.

Valticos N., International Labour Law, Kluwer, Deventer 1979, https://doi.org/10.1007/97894-017-4402-7.

Valticos N., Potobsky G., International Labour Law, Kluwer Law and Taxation Publishers, Deventer 1995.

Zasztowt-Sukiennicka H., Międzynarodowa Organizacja Pracy, Wydawnictwo Ludwika Chomińskiego, Warszawa-Wilno 1929.

Zdanowski A., Międzynarodówka zawodowa w świetle uchwał, „Robotniczy Przegląd Gospodarczy" 1926, nr 9.

Ziemięcki B., Międzynarodowa Konferencja Pracy, „Robotniczy Przegląd Gospodarczy” 1927, nr 7. 